\title{
LEVELING THE ICE The Discrepancy Between Male and Female Athletics at Boston College
}

ISABELLE KENNEDY, MOLLY MCCABE, KATELYN RODGERS

THIS PAPER EXPLORES MULTIPLE PUBLISHED ARTICLES REGARDING THE SOCIETAL ASSUMPTION THAT WOMEN'S SPORTS ARE LESS COMPETITIVE AND LESS ENGAGING THAN MEN'S SPORTS. SOME ARTICLES, SUCH AS WOMEN'S SPORTS FOUNDATION (2010) AND CARPENTER \& ACOSTA (2005), CITE LACK OF FUNDS AND MEDIA VISIBILITY AS TO WHY WOMEN'S SPORTS ARE NOT AS HIGHLY REGARDED AS MEN'S SPORTS. OTHER ARTICLES, SUCH AS MESSNER (2000) AND NWLC (2O12), EXPLAIN THAT THE DISPROPORTION IN COVERAGE OF MEN'S AND WOMEN'S SPORTS IS BASED ON SOCIETY'S EXPECTATIONS OF WOMEN AND THE ASSUMPTION FEMININE“WEAKNESSES" THIS PAPER EXAMINES THE MEN'S AND WOMEN'S ICE HOCKEY TEAMS AT BOSTON COLLEGE AND DETAILS THE ISSUES SURROUNDING TEAM SCHEDULES, FAN ATTENDANCE, UNIVERSITY SUPPORT, AND MEDIA PRESENCE IN AN ATTEMPT TO DETERMINE WHETHER BC WOMEN'S ICE HOCKEY RECEIVES DIFFERENT LEVELS OF SUPPORT AND INVESTMENT FROM BC COMPARED TO THE BC MEN'S HOCKEY TEAM, AND WHETHER THIS DIFFERENTIAL INVESTMENT LEADS TO A UNIQUE SPECTATOR EXPERIENCE THAT MAY EXPLAIN THE LACK OF SPECTATOR ATTENDANCE AT BC WOMEN'S HOCKEY GAMES. 


\section{INTRODUCTION}

Since its introduction in I978, competitive women's sports have consistently been viewed as less competitive, less entertaining, and less worthy of spectator support than men's sports. Consequently, men's sports enjoy large spectator and fan bases while women's sports often struggle to draw fans, resulting in fewer, less lucrative professional opportunities for female athletes. We, however, challenge this stereotype; women's sports are often just as competitive as men's sports, and are equally worthy of spectator support. In her article, "Exposing Sport as a Continuum" (I995), Kane argues that the separation of men's and women's sports protects the myth of biological determinism, which uses sport as proof that men are naturally superior to women. We argue that this stereotype has been used to justify the lack of spectator support for women's sports, precluding an examination of spectator support as an aspect of the unequal gender hierarchy within sporting structure.

Professional female athletes are paid significantly less than their male counterparts. In fact, the National Women's Hockey League (NWHL), established in 20I5, is the first women's hockey league to pay its players a salary. However, the women's league still has a long way to go to become equal with the men's league. The team salary cap for the NWHL is $\$ 270,000$, with the highest paid players receiving $\$ 22,000$ per year (which is not a living wage in most American cities). In contrast, in the National (Men's) Hockey League (NHL), the lowest paid players are paid $\$ 500,000$ per year-nearly double the salary cap of an entire NWHL team (Larkin, 20I5). The average salary for a player in the NHL is \$2.4 million per year (McKinven, 20I5). As John Smallwood (20I7) points out, professional female players receive only a fraction of the salary of male players because women's games generate only a fraction of the profit of men's games. However, in attempting to justify why professional female athletes should be paid less, Smallwood fails to explore why women's games generate less money.

Spectator sports function as social and cultural events, which, to a great degree, owe their existence to media and advertising. A sporting event requires a significant investment to become a spectator event. A team, club, or league must make a monetary investment in the infrastructure of spectator sport, including (but not limited to): pre-, during-, and post-game talk shows and announcers; TV and media coverage; spectator and fan events, tailgating, giveaways, and promotions; and concessions and player merchandise. Together, these factors create an atmosphere that transforms a sporting competition into a spectator event. In turn, the spectators create advertising opportunities that are the basis of profit generated by the game. This is a long-established pattern in the world of men's sports, where years of investment have created clubs with generations of spectator-following and complex systems of media coverage.

However, there is a dearth of similar investment in women's sports. While women's sports receive little to no mainstream media coverage, men's sports make up 96\% of all network sports coverage (Women's Sports Foundation, 2010). The lack of audience at women's sporting competitions is often used to justify the lack of investment in the infrastructure of spectator sport, as John Smallwood proposed. The assumption follows that because women's sports are not currently producing a significant profit, no further investment should be made in the spectator infrastructure. However, without an attempt to promote women's sports as spectator events, women's sports will continue to fail to draw crowds and consequently fail to turn a profit. This assumption becomes cyclical, allowing stereotypes about women's sports to take the blame for the lack of spectator attendance. This narrative accuses women's inferior playing ability for the lack of spectator fan base, as though women's sports have lost their fan base due to their supposed lack of skill, when in fact women's sports, particularly women's hockey, have rarely had any spectator support at all. Women's sporting events fail to turn the kind of profit that men's sporting events do because of a lack of spectator fan base, which is due primarily to a lack of investment in women's sports as spectator events. This lack of profit results in poor pay for female athletes and a shortage of professional opportunities for women in athletics. The lack of profit should not be used to justify a lack of investment in spectator infrastructure, as it is this very investment that would eventually result in an increase in spectators at women's sporting events, and therefore, an increase in profits. Investing in this sporting infrastructure would be a critical step in rectifying the inequality between men and women's sports.

We believe that the lack of investment in spectator infrastructure for women's sporting events constitutes a violation of the equality required by Title IX. This is a critical problem because the fan bases of collegiate sports 


\section{"Women's sporting events fail to turn the kind of profit that men's sporting events do because of a lack of spectator fan base, which is due primarily to a lack of investment in women's sports as spectator events."}

feed directly into professional sports. Title IX lays out a series of measures based on the three criteria of proportionality, progress, and satisfied interests by which equality can be determined: scheduling of games and practice time, equal publicity, and failure to provide the necessary funds required for teams to access equal opportunity (Carpenter \& Acosta, 2005). Furthermore, financial support for one team over another may be considered a "possible pretext for discrimination" (Carpenter \& Acosta, 2005). As a result, we decided to examine Women's Ice Hockey (WIH) at Boston College. More specifically, we researched whether BC's investment in spectator infrastructure is equal for the men and women's hockey teams. At the onset of this project we hypothesized that a) investment in spectator infrastructure for BC WIH is much lower than the investment in Men's Ice Hockey (MIH), and b) that this functions as a major source of the disparity in spectator turnout at these events. Our hypothesis directly challenges the assumption that lack of support for women's sports is due solely to the "fact" that women's sports are less entertaining or competitive than men's sports.

We chose Women's Ice Hockey specifically because WIH at $\mathrm{BC}$ is a prime example of a sport which, statistically, justifies a solid fan base. Of the four major winter sports sponsored at BC, including Women's and Men's Basketball and Ice Hockey, Women's Ice Hockey has been the most successful in recent years. In the 2015-16 season, the team went undefeated until the Frozen Four of the NCAA championships, and in 20I6-I7 won the Beanpot and made it to the semifinals of the NCAA championships, beating out the men, who failed to make the NCAA tournament. WIH had a 25-6-5 win record for the season, winning $69 \%$ of all games, while MIH had a $2 \mathrm{I}-\mathrm{I} 5-4$ win record, winning only $52 \%$ of all games. In short, the success of WIH at BC easily justifies a robust fan base. We sought to determine whether $\mathrm{BC}$ WIH receives different levels of support and investment from $\mathrm{BC}$ as an institution compared to the BC men's hockey team, and whether this differential investment leads to a different spectator experience that may explain the lack of spectator attendance at BC women's hockey games.

\section{METHODS}

To conduct our research, we attended a total of four women's home games and four men's home games during the season. We divided this work by attending at least one women's game and one men's game each, and then splitting up the remainder of the games that were left. It was important for each member of our group to attend at least one game of each team in order to make comparisons between them. We recognize that four games of each team is not representative of the whole season and could be a potential limitation of our study, but we were limited on available games left since the study began during a second semester class. In addition, we found it sufficient enough to collect reasonably accurate data of the sports culture surrounding hockey at BC. The timing of our study (second semester, post-Beanpot Tournament) could also be a potential limitation, as early-season games often enjoy larger crowds of BC students looking to parlay Gold Pass points into Beanpot tickets.

While we were observing each game, we collected research on the pep and cheering taking place, music, JumboTron effects, concession stands, and crowd dynamics. The BC Gold Pass application on our phones allowed us to verify the number of students who checked into each game as well as the number of points awarded for checking in. Since the BC Gold Pass app only tracks student attendance, taking pictures of the crowd allowed us to see how full the stands were separate from the student section (alumni, professors, visiting team guests, community members, etc.). A sample of these pictures can be found below. Additionally, we followed social media outlets to watch for the scheduling, promotion, and coverage of games. We were unable to stay for the entirety of a few of the games, providing a limitation for our research, as wecould not examine whether crowds remained constant for the full game. 


\section{RESULTS AND DISCUSSION}

The results of our study were essentially consistent, but were still intriguing to prove. The men's games had Baldwin, the band, and much more pep and cheering from the crowd, while the women's games never had the band and often did not have Baldwin except for special circumstances. The men's games featured more modern, pump-up, energizing music, while the women's games were characterized by organ music and a much quieter, subdued overall atmosphere. It was particularly shocking that the band played "For Boston" after every score made by the men's team, just like football and basketball games, but BC did not even play a recording of "For Boston" for the women's hockey team. Not even playing a recording of the victory song when they score devalues the work and success the female players experience.

All Ig of the concession stands were open throughout the men's games while the women's games usually offered no concessions, or just one for hot chocolate when it was snowing outside. Social media coverage of the men's games was much more frequent including more action on the JumboTron. Student check-ins on the Gold Pass application were usually over I50 for the men's games and under 25 for the women's games. Crowds for the men's game were often made up of both students and families, but the women's games were mostly families with young girls, potential hockey players themselves who might look up to the BC players. The emotion and intensity during sporting events with larger crowds is palpable and further influences even more people to attend. Players are also likely to feed off this energy, so the women's games that have hardly anyone in the crowd do not appear as inviting and do not act as a support system for the women.

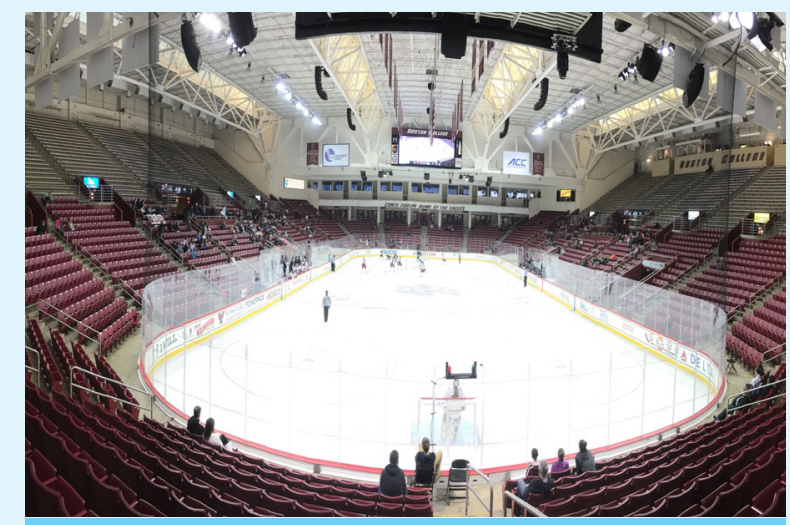

BOSTON COLLEGE WOMEN'S HOCKEY GAME CROWD.
In-game entertainment was much more prevalent during the men's games as well. BC offered captains' puck giveaways, sledding races, goal shots, and many other games or forms of entertainment between periods to keep the crowd interested. As a result, men's games become a social gathering where spectators can simply enjoy the experience with friends even if they are not actually interested in hockey, but the women's games are mainly targeted only to dedicated hockey fans. This can also be seen in the fact that men's games cost money and offer season tickets for purchase whereas the women's games have free entrance. We would think free entrance would be a positive opportunity to promote spectatorship, but the fact that men's games are often soldout despite costing money and the women's games are empty when they are free demonstrates the lack of interest for female sports and lack of effort $\mathrm{BC}$ is putting into promoting them or making them inviting. Schools place an emphasis on spectator sports teams' revenue production rather than realizing the lifelong health benefits of participating in physical activity and social interaction, which leads to a higher level of importance placed on men's hockey as compared to women's hockey (Boutilier \& SanGiovanni, I994). This distinction can be seen in the fact that the BC women's team has statistically been performing better than the men's team recently, but the school values the promotion of the men's team and their revenue more. Furthermore, we noticed that none of the retired jerseys hanging up in the stadium are a woman's.

We also analyzed the scheduling of games between women's and men's hockey. Title IX indicates that scheduling of games is a measure by which equality should be determined (Carpenter \& Acosta, 2005). We define primetime

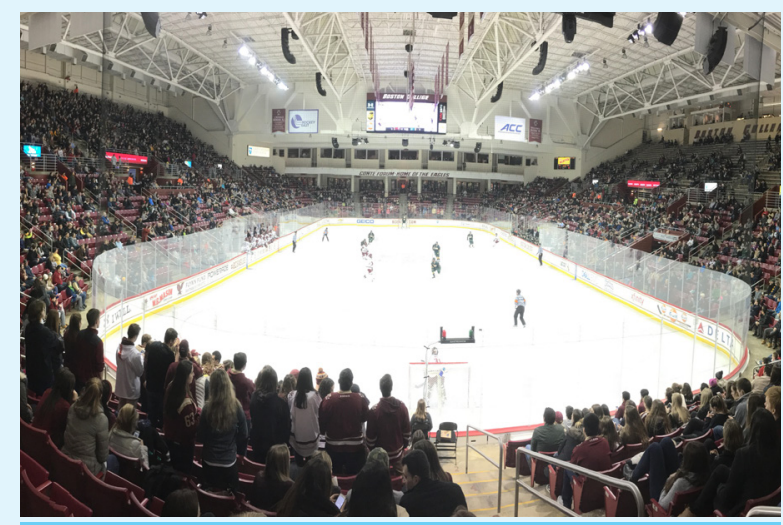

BOSTON COLLEGE MAN'S HOCKEY GAME CROWD. 
games as games taking place Friday or Saturday evenings after 6 PM or Sunday afternoons between I-5 PM, as these are times during which spectators are most likely to be able to attend. In addition, these games line up with traditional primetime TV coverage windows. Of the I9 games played on campus by the BC women's team, only five were played at primetime, while nine of the men's I7 games were played during this timeframe. BC clearly favors men's games over women's games for primetime slots. However, sometimes BC is not in charge of game scheduling-because of this, we also analyzed game scheduling across the whole season. The women's and men's teams each played 4I games throughout the season. However, of those 4 I games, 25 men's games were at primetime, while only nine of the women's games were at primetime. Clearly, the unequal scheduling of games is an NCAA-wide epidemic and violation of Title IX.

Boutilier and SanGiovanni (I994) examine these differences in BC hockey with a socialist feminist lens that recognizes economic inequality and sexism as significant forms of oppression. BC's two hockey teams play in the same venue and have the same access to equipment, locker rooms, and quality coaches because Title IX requires it, but the differences in times of game, promotion, cost, concessions, and pep are all differences that give unfair treatment by prioritizing the men's team. These differences in opportunity and treatment of the two teams is related to much of the data presented by the National Women's Law Center (20I2). More than half of the students at NCAA schools are women, but they receive only $44 \%$ of the opportunities. Female athletes at these schools receive only $28 \%$ of the total money spent on athletics, 3 I $\%$ of the recruiting dollars, and $42 \%$ of the athletic scholarship dol-

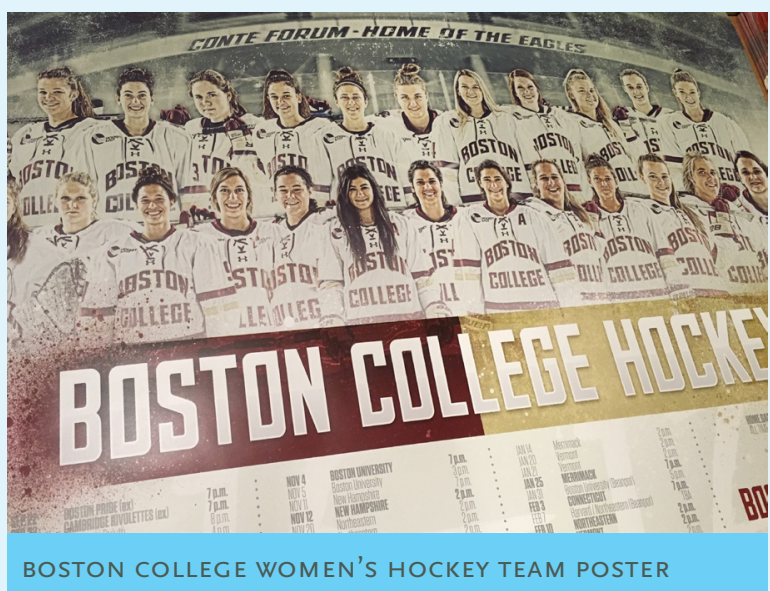

lars-a separation of funds that is clearly not equal. Also according to the NWLC (2OI2), for every dollar spent on women's sports about $\$ 2.50$ is spent on men's sports. Putting more effort into the men's sports because they are revenue sports does not qualify for equality under Title IX on Boston College's campus.

Our research outside of the games themselves, including social media and promotional measures, provided supporting evidence of the discrimination of the women's hockey team. The posters for scheduling of games portray the men's team with aggressive stances, emphasizing their masculinity and athleticism, while the women's team is perfectly lined up and smiling. Messner (2000) argues that each sex typically takes on the role of a warrior narrative vs. a Barbie narrative and uses daily interactions, such as posing for a picture, to create and recreate gender in daily interactions. Warrior narratives can be used to justify violence in men's sports, particularly the violent nature of hockey, when it is used as a struggle between good and evil to defeat the opposing team. This justification of aggression does not hold true for women who are expected to maintain their feminine appeal and play more conservatively in a "men's sport." Portraying the teams differently on their posters allows for BC to emphasize the differences between them rather than seeing the fact that they are all hockey players and celebrating their athleticism.

Lucas and Smith (I978) also suggest ideas that can also be used to analyze these promotional posters. They discuss the women's anti-competitive movement as one of the initial programs that was against women's sports. The movement gained traction when they presented their original argument to the International Olympic Committee (IOC)

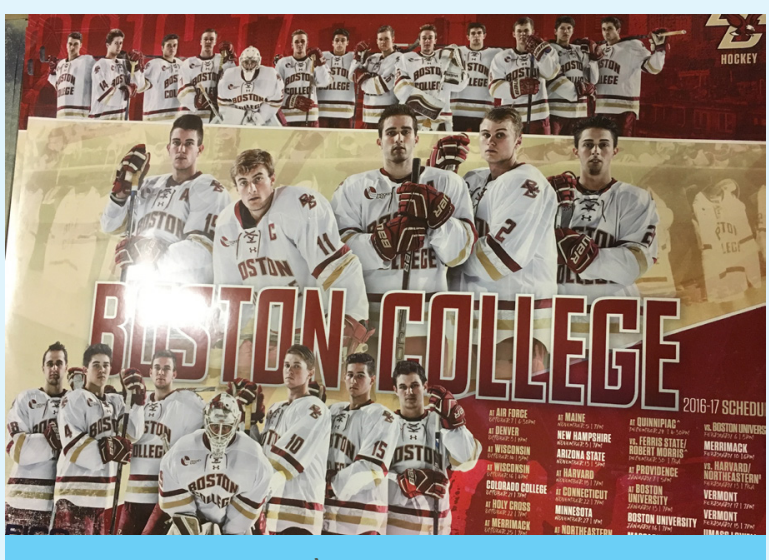

BOSTON COLLEGE MEN'S HOCKEY TEAM POSTER

\section{9 \\ 9}

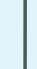

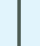




\section{"Highlighting her family role trivializes her athleticism in the same way that all female athletes are expected to place their role as women ahead of their role as athletes."}

that women's sports were "impractical, uninteresting, wrong, and that watching them was undignified," an attitude that has not changed much despite the common occurrence of as made evident by the difference in treatment (Lucas \& Smith, I978). At one time, it was believed that women were incapable of prolonged physical activity and that they should not participate in men's sports for health reasons including childbearing. On the contrary, however, sports actually have a positive impact on women's health according to the NWLC (2OI2). Studies have shown that participating in athletics reduces the risks of heart disease, osteoporosis, and breast cancer for women. Since the implementation of Title IX, obesity in girls has decreased by 7\% (NWLC, 20I2). Despite this, it is still a common belief that certain sports such as hockey are too aggressive for women and that their games are thus much calmer and more subdued than men's games. In order to combat discriminatory media portrayals, the highly successful, multidisciplined Babe Didrikson changed her clothes, her hair, started wearing high heels, and married a professional wrestler, but her strength was still decidedly unaccepted (Lucas \& Smith, I978). The women in this poster smiling and needing to appear attractive, emphasizing their femininity rather than their athletic accomplishments, is similar to Didrikson's achievements being questioned for her femininity and estrogen levels.

Media depictions of female athletes also often focus on their family or roles as mothers, as can be seen in the works of American writer Nancy Lopez, as discussed by Jamieson (I998). Highlighting her family role trivializes her athleticism in the same way that all female athletes are expected to place their role as women ahead of their role as athletes. Race, class, and gender are distinguishing characteristics in sport settings, especially in the creation of masculinities and femininities. Furthermore, Lopez's marriage demonstrates a heteronormative relationship with hegemonic gender hierarchies. Lopez's husband supports her without being a part of her sport and does not have her bring it home to the family, but Lopez constantly helps him practice his sport at home (Jamieson, I998). Race played an important role in her background, which is a noteworthy aspect within all hockey domains including
$\mathrm{BC}$ because both the men's and women's teams are almost entirely made up of white players. Hockey may lack racial diversity because it is such an expensive sport and women of color often have lower socioeconomic status (SES) that may prevent them from playing. These factors influence who is able to participate in women's sports and interact with each other to make experiences unique; "only $64 \%$ of African American and Hispanic girls and 53\% of Asian girls play sports, while $76 \%$ of Caucasian girls do" (NWLC, 20I2). Therefore, the racial disparities in women's sports continues to show the unfair treatment that is stereotyped in society.

We also analyzed the Instagram photos that @BCAthletics posted regarding the men's and women's teams. From this past season, the women's team was featured 38 times, while the men's team was featured 26 times. This was surprising because one would assume that the men's team would be featured more often than the women. However, when actually looking at the photos, we noticed that the men's posts were often before their games and were encouraging fans to come to the home games. The women's posts were mostly post-game statistics or individual player accolades. So, while technically the women are showcased more than the men's team on the Boston College Athletics Instagram page, the women are still being disadvantaged because their team is not being promoted as a spectator sport. In one instance, Boston College led a social media campaign to help achieve a soldout men's hockey game for the match against Notre Dame. This campaign was successful, which was an exciting feat for the men's team. However, BC has never made such an effort for the women's team.

Besides social media posts advertising athletic events on campus, BC Athletics also sends out emails to Gold Pass members to remind them of upcoming games and competitions. One email sent out during the year showcased a men's hockey game, a women's hockey game, and a women's basketball game. The men's hockey game was featured and shown at the top with bright colors and bold lettering and the graphic used was bigger than the women's hockey and basketball, which were considered "other 
games" happening on campus. The other two graphics were greyed out and one had to look closely to see that it was actually the senior night for both of these women's teams. It was also advertised on the women's graphics that both games were free admission. Under Title IX, the email should have shown equal attention to all three teams and included similarly themed and sized graphics.

The disproportionate treatment of men's and women's ice hockey is not limited to Boston College. Recently, the US Women's National Team threatened to boycott the World Championships because they believed they were being treated unfairly in comparison to men. According to Garcia (20I7), the US Men's Hockey Team was being flown in first class, had family members stay for free, and each player was given his own hotel room to sleep in. In contrast, the women's team was flown out in coach, they could not have their family members paid to fly to the games, and the women often had to share hotel rooms with teammates (Garcia, 20I7). As stated in Title IX, men's and women's teams must be treated equally, which would include the women receiving the exact same travel arrangements as the men's team. They were supported by organizations such as the NFL, NBA, and MLB. The Men's National Team even threatened to boycott as well if the women's demands were not met (Garcia, 20I7). An agreement was eventually made between the league and the women's team, but the fact that they had to go to such extreme measures to get equal treatment is troubling. This is especially relevant to Boston College Women's Hockey because six current and former players were on that team. The women's team eventually went on to take home gold in the championship.

The women's team also made it a point to not only explain the situation from their perspective, but they also made the issue broader to encompass all women that are affected by unfair treatment because of their gender. According to Macur (20I7), Meghan Duggan, the team's captain, stated, "We want to do the fair thing, and the right thing - not just for hockey but for all women." The team recognized that this is not an issue that only relates to their sport or their race, but that it is a problem that all women face in some shape or form. This can be analyzed with Crenshaw's (2006) importance of intersectionality. Crenshaw (2006) states that women have come to realize that many voices together is more successful than one voice alone. Women have made strides throughout history by coming together to support various causes, such as the right to vote. There are differences between races that must be understood and included in these fights, but there are also differences within racial groups as well. The US Women's Hockey team, while not going into a deep analysis of how sexism affects women differently depending on criteria such as race and socioeconomic status, did acknowledge that their specific team is not the only women that experience unfair treatment based on sex or gender.

\section{CONCLUSION AND RECOMMENDATIONS}

We believe that Boston College is investing fewer resources in promoting women's hockey as a spectator event, an act that further perpetuates the stereotypes that women's hockey and women's sports in general are less interesting, competitive, and spectator-worthy than men's sports. While it has been over 40 years since the implementation of Title IX, men's and women's sports are still unequal. The lack of investment on the part of Boston College in spectator infrastructure for Women's Hockey may not directly cause the lack of spectator attendance at women's games, but it certainly extends the issue. Considering the significant difference in professional opportunities for men and women, the lack of fan support at the collegiate level produces and maintains disparate outcomes for women and men's sports. It is not only important for women's hockey to receive more university support because the players deserve it, but also because the majority of fans at these women's games are young female hockey players. When these girls see empty stands, they get the impression that their sport does not matter. Some of these girls may feel discouraged and decide to quit hockey for a sport deemed more "feminine." The very best talent in women's hockey may never make it to the collegiate level because they are receiving messages that, as athletes, they will never be valued as highly as men.

In light of our research findings, we believe that unequal spending on the part of NCAA institutions in women and men's sports must be considered discriminatory. In order to combat this lack of support, Boston College can make an effort to promote the women's hockey games more on social media and around campus. Shortly after the passage of Title IX, the Association for Intercollegiate Athletics for Women (AIAW) reimagined the world of sports, placing a significant emphasis on requiring equal network TV coverage of all women and men's sports, increased commitment to bringing in spectators, and paid particular attention to ensuring that funding was not allocated primarily to money making sports, but rather spread out evenly to all 
sports (Slatton, I982). These are reasonable, attainable measures which Boston College and the NCAA can take in order to increase spectator and fan attendance. To start, the women's team should get a sign on the parking garage similar to what the men's and women's basketball teams have, along with the men's hockey team. Boston College should also utilize their social media pages to encourage fans to attend the women's games. While the BC pages have a myriad of posts involving the women's team, their posts are mainly post-game statistics. They rarely, if ever, post before their games. They should be posting before home games to entice more student fans to attend the games. Additionally, Boston College and the NCAA equalize the scheduling of games across the season, allowing men and women the opportunity to play at times that are easily accessible for spectators. Finally, Boston College must make a concerted effort to invest in spectator infrastructure by increasing the number of concession stands and effects at women's games, energizing the atmosphere by inviting the band, and increasing spectator events and promotions at the games. Though it is unlikely that a robust fan-base for women's hockey will emerge overnight, taking these steps to ensure equitable investment in men's and women's sports will begin the long process of creating an equal playing field for all athletes.

\section{REFERENCES}

Boutilier, M., \& SanGiovanni, L. (I994). Politics, public policy and Title IX: Some limitations of liberal feminism. In S. Birrell \& C. Cole (Eds.), Women, Sport \& Culture. (pp. 97-I09). Champaign: Human Kinetics.

Carpenter, J.J., \& Acosta, R.V. (2005). Title IX. Chapter I. The law. (pp. 3-33). Champaign,IL: Human Kinetics.

Crenshaw, K. (2006). Mapping the margins: Intersectionality, identity politics, and violence against women of color. In I. Grewal \& C. Kaplan (Eds.), An Introduction to Women's Studies: Gender is a Transnational World. 2nd Ed. (pp. 200-206). Boston: McGraw-Hill.

Garcia, A. (20I7). While the U.S. men's hockey team sat in business class, the women sat in coach. Retrieved April Io, 20I7, from http://money.cnn.com/20I7/03/24/news/ companies/usa-hockey-womens-pay-dispute/

Jamieson, K. (1998). Reading Nancy Lopez: Decoding representations of race, class, and sexuality. Sociology of Sport Journal, I5. 343-358.

Kane, M.J. (I995). Resistance/Transformation of the oppositional binary: Exposing sport as a continuum. Journal of Sport and Social Issues, I9 (2). I9I-2I8. W-I4.

Larkin, M. (2015, September 28, 20I5). And the highestpaid player in women's hockey is... The Hockey News.

Lucas, J., \& Smith, R. (1978). Women's sport: A trial of equality. In The Saga of American Sport. (pp. 342-372). Philadelphia: Lea \& Feinberg.

Macur, J. (20I7). U.S. Women's Hockey Team Boycott Echoes a Fight That Isn't Over. Retrieved April Io, 20I7, from https://www.nytimes.com/20I7/03/I5/sports/hockey/uswomen-world-championship-boycott-contract.html.

McKinven, J. (2015). The hierarchy of pro hockey. Retrieved from https://glassandout.com/2015/09/the-hierarchy-ofpro-hockey/.

Messner, M. (2000). Barbie girls versus sea monsters: 
Children's constructing gender. Gender \& Society, I4(6). $765-784$.

National Women's Law Center. (2012). The Next Generation of Title IX: Athletics.

Slatton, B. (I982). AIAW: The greening of American sport. In J. Frey (ed.), The Governance of Intercollegiate Athletics. West Point: Leisure Press.

Smallwood, J. (20I7). Smallwood: Women's national hockey team pay argument doesn't hold up. Retrieved from http://www.philly.com/philly/blogs/pattisonave/ women-USA-Hockey-pay-dispute-Olympics-equal.html.

Women's Sports Foundation. (2010). Women play sports but not on TV. Retrieved from https://www. womenssportsfoundation.org/research/article-andreport/media-issues/women-play-sports-not-tv/.

LEVELING THE ICE 